October 19, 2009

Melissa Bates

U.S. Department of Energy

Idaho Operations Office

1955 Fremont Avenue, MS 1235

Idaho Falls, ID 83415

Reference: $\quad$ Cooperative Agreement DE-FC07-08ID14899

Sulfur-Iodine Integrated Lab Scale Experiment Development

(GA Project 30300)

Dear Ms. Bates:

Enclosed for your use and information is one copy of the following report prepared under the referenced Cooperative Agreement

\begin{tabular}{c|c} 
GA REPORT & TITLE \\
\hline GA-C26575 & "Nuclear Hydrogen Initiative, Results of the \\
& $\begin{array}{c}\text { Phase II Testing of Sulfur-Iodine Integrated } \\
\text { Lab Scale Experiments, Final Report" }\end{array}$ \\
\end{tabular}

If you have any questions or comments, please do not hesitate to contact me by telephone at 858.455.3057, at FAX 858.455.3545 or by E-mail at Ramona.Gompper@gat.com.

Sincerely,

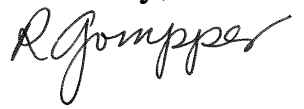

Ramona Gompper

Sr. Contract Administrator

Enclosure: As stated

Distribution by e-mail:

batesmc@id.doe.gov

psdrept@id.doe.gov

carl.sink@nuclear.energy.gov 


\title{
NUCLEAR HYDROGEN INITIATIVE, RESULTS OF THE PHASE II TESTING OF SULFUR-IODINE INTEGRATED LAB SCALE EXPERIMENTS, FINAL REPORT
}

\author{
by \\ R. MOORE, ${ }^{\star}$ G. NARANJO, ${ }^{*}$ B.E. RUSS, W. SWEET, M. HELE, ${ }^{\dagger}$ \\ and N. PONS ${ }^{\dagger}$
}

*Sandia National Laboratories.

'Commissariat à l'Energie Atomic (CEA).

Prepared for

the U.S. Department of Energy

under Contract No. DE-FC07-08ID14899 



\section{EXECUTIVE SUMMARY}

Sandia National Laboratories (SNL), General Atomics Corporation (GA) and the French Commissariat à l'Energie Atomique (CEA) are participants in a international collaborative effort to construct a laboratory-scale Sulfur-Iodine (S-I) process capable of producing 100-200 L/hr of hydrogen. This project is being conducted as an International Nuclear Energy Research Initiative (INERI) project supported by the CEA and the U.S. Department of Energy (DOE) Nuclear Hydrogen Initiative. The process has been constructed at the GA facility in San Diego, CA and testing is ongoing. This report discusses the results from Phase II testing and documents the completion of the milestone titled "Results of the Phase II Testing of the S-I Integrated Lab Scale Experiment" for this work.

The S-I cycle consists of three main processing steps: thermal decomposition of sulfuric acid, production of hydrogen iodide and the decomposition of hydrogen iodide to produce hydrogen. SNL is responsible for the sulfuric acid decomposition section, the CEA the hydrogen iodide production section and GA the hydrogen iodide decomposition section. The process sections are constructed on skids and are integrated through a chemical storage skid. All chemicals used in the process are transferred between the skids through the chemical storage skid with the exception sulfur dioxide that is transferred directly from the SNL skid to the CEA skid.

Phase I of this project involved integration of the three process sections into a complete S-I cycle. The initial integrated operation was performed in April of 2008 and is documented in the SAND Report titled "Results of Phase I Testing of the Sulfur-Iodine Integrated Laboratory-Scale Experiment." Phase II of the work includes completion of initial integrated shakedown operations, control verification tests (interface skid operations, production rate tests, shutdown tests), transient response tests (startup, shutdown, flow rate perturbations, mismatched flow rates), and cross talk tests (inter skid contamination and response) and process improvements or modifications as budgets permit. The results from Phase I of the project along with additional stand-alone and integrated tests have identified issues for each process section that have been addressed in Phase II work. These include redesign and replacement of major system components, corrosion control and modification of process monitoring. Several identified problems have led to very significant process modifications. However, for all three process sections, all major modifications have been completed.

The GA hydrogen iodide section has undergone several modifications and has been successfully operated multiple times to produce hydrogen. The hydrogen iodide reactor has been replaced with a smaller unit to decrease the time for preheating the unit and reach equilibrium while operating. Using the smaller reactor, hydrogen has been produced at a rate of 10 to $75 \mathrm{~L} / \mathrm{hr}$. Problems with differential pressure cells used throughout the process for monitoring and control have been eliminated by replacing the units with higher quality units. Ta alloy corrosion problems were encountered due to 
hydrogen embrittlement of Ta vessels and piping. Most of these issues have been mitigated for the ILS with either modified operational conditions, or periodic replacement. Long-term solutions are being developed and will be tested in FY09.

The CEA has completed major modifications to the Bunsen section and the section is ready for additional testing of the Bunsen reactor at this time. Completed modifications include: installation of a new Bunsen reactor equipped with Raching ring packing and differential pressure cells for enhanced process control and a redesign and modification of the system for transferring iodine from the chemical storage skid to the CEA skid. In addition to these modifications, additional integrated testing with the SNL acid decomposition section has been completed and the transfer of chemicals between the CEA section and the SNL sections is now considered routine. The CEA will begin testing the new Bunsen reactor within the next few weeks as part of integrated operation with the SNL process section.

In the SNL acid decomposition section, system modifications include incorporation of an acid neutralization step to the process cooling water system to prevent corrosion of the circulating water chiller used in the process, an increased efficiency of the acid concentrator and the addition of a pressure control system to maintain a constant pressure in the acid decomposer. The acid decomposition process has been successfully operated multiple times over the past five months in the stand-alone and integrated modes. In the last operations of the process, the effect of temperature on acid decomposition was determined at a pressure of 1 bar. The results indicate the production of sulfur dioxide begins to decrease between $750^{\circ} \mathrm{C}$ and $800^{\circ} \mathrm{C}$ with a decrease in gas production of $50 \%$ at $700^{\circ} \mathrm{C}$. No sulfur dioxide was detected at $650^{\circ} \mathrm{C}$.

The GA hydrogen iodide decomposition section and SNL acid decomposition section of the S-I process are ready for additional integrated testing. All modifications have been completed and successful stand-alone tests have been performed with the new equipment. Major equipment modifications have been completed to the CEA section and the process is ready to begin testing of the newly installed Bunsen reactor. Testing of the Bunsen reactor will be performed in the stand-alone and integrated mode. 


\section{TABLE OF CONTENTS}

EXECUTIVE SUMMARY

1 INTRODUCTION ............................................................................................................................................

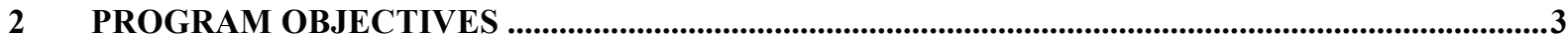

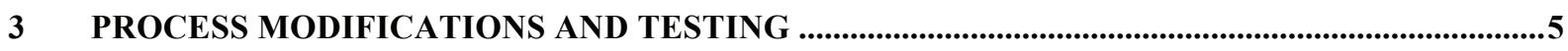

3.1 HYDROGEN IODINE PRODUCTION, BUNSEN REACTION (FRENCH CEA) ............................

3.1.1 Issues Identified From Initial Integrated Tests ................................................................ 5

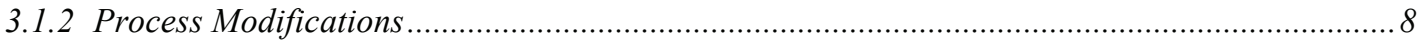

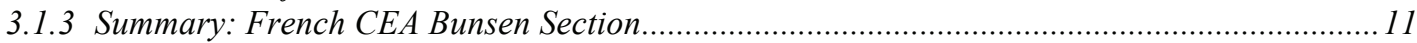

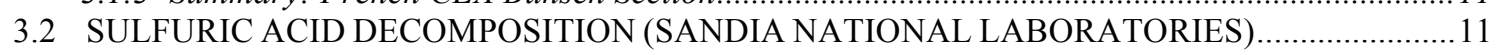

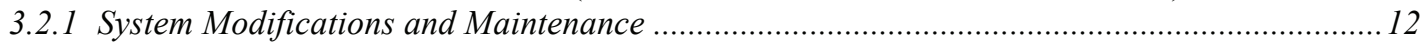

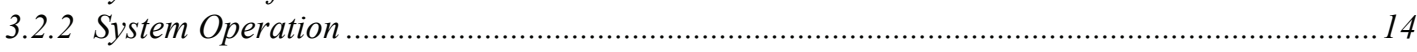

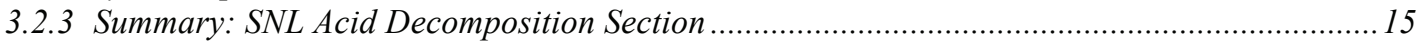

3.3 HI DECOMPOSITION SECTION DEVELOPMENT (GENERAL ATOMICS) …………................................. 16

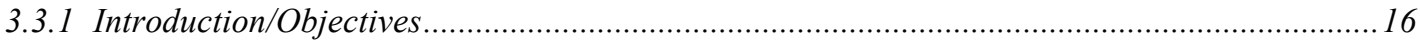

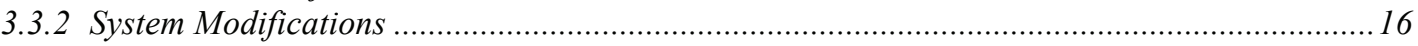

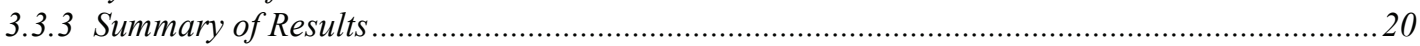

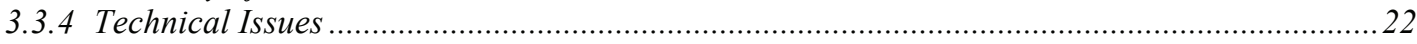

3.3.5 Summary: GA Hydrogen Iodide Decomposition Section ........................................................2 24

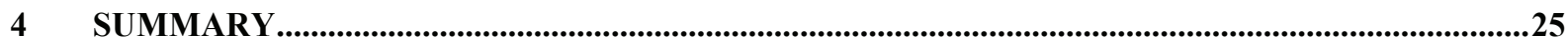



Nuclear Hydrogen Initiative, Results of Phase II Testing OF the Sulfur-Iodine

\section{LIST OF FIGURES}

FIGURE 3. 1 COLLECTED IN SKID 1 AT THE EXIT OF THE BUNSEN REACTOR …..........................................................

FIGURE 3. $2 \mathrm{H}_{2} \mathrm{SO}_{4}$ COLLECTED ONLINE IN THE DENSITY CONTROL CELL …...........................................................

FIGURE 3. 3 SCHEMATIC OF THE NEW UPPER PART OF THE BUNSEN REACTOR ....................................................

FIGURE 3. 4 SCHEMATIC OF THE BUNSEN REACTOR WITH DP CELLS AND RASCHIG RINGS .....................................10

FIGURE 3. 5 CALIBRATED ORIFICE AND VIEW OF THE SYSTEM WITH THE TWO DP CELLS .......................................11

FIGURE 3. 6 INNER DECOMPOSER TUBE SHOWING CATALYST PELLETS SECURED TO TUBE WITH A SHEET OF

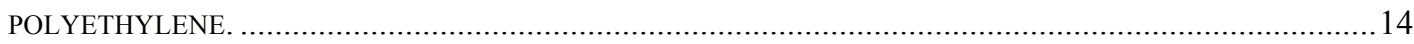

FiguRE 3. 7 NEW 2" DiAMETER REACTOR VESSEL B) OLD 6" DIAMETER REACTOR VESSEL ……............................17

FIGURE 3. 8 REPRESENTATIVE HEAT UP TIME FOR 6" DIAMETER REACTOR..........................................................17

FIGURE 3. 9 REPRESENTATIVE HEAT UP TIME FOR 2" DIAMETER REACTOR........................................................ 18

FIGURE 3. 10 TYPICAL FEED TANK DP READINGS FOR A RUN ………..................................................................19

FIGURE 3. 11 TYPICAL HI DISTILLATION TEMPERATURE PROFILE ……...........................................................20

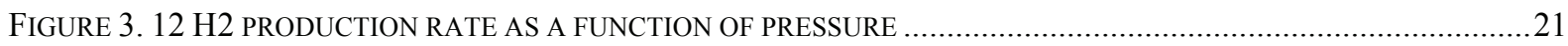

FigURE 3. 13 PRESSURE AFFECT ON HI DiSTILLATION BOILER TEMPERATURE …..................................................21

\section{LIST OF TABLES}

TABLE 1 RESULtS FROM ANALYSIS OF BUNSEN REACTION PRODUCTS .................................................................

TABLE 2 OPERATIONAL PARAMETERS FOR TEMPERATURE DEPENDENCE TESTING ……...........................................15

TABLE 3 RESULTS For TEMPERATURE EFFECT ON DECOMPOSITION EFFICIENCY ..................................................... 15

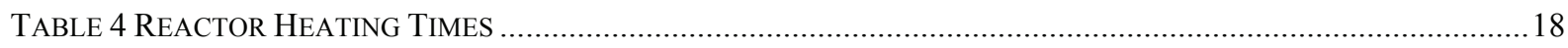

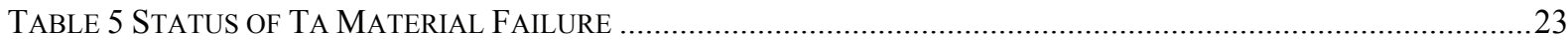





\section{INTRODUCTION}

An international collaborative effort between Sandia National Laboratories (SNL), General Atomics Corporation (GA) and the French Commissariat à l'Energie Atomique (CEA) has been undertaken to investigate Sulfur-Iodine (S-I) thermochemical cycles for the production of hydrogen from water. This project is being conducted as an International Nuclear Energy Research Initiative (INERI) project supported by the CEA and the US DOE Nuclear Hydrogen Initiative. The integrated experiment is being performed at the GA facility in San Diego, CA where the process sections have been constructed and are undergoing testing. The objective of the program is to demonstrate thermochemical hydrogen production at a rate of 100 to $200 \mathrm{~L} / \mathrm{hr}$ in a process utilizing scalable technology that enables the design of a larger pilot-scale process in the future. This reports documents phase II activities for the program.

Each participant in the work is responsible for the design, construction, stand-alone testing and integrated operation of a section of the S-I cycle. SNL is responsible for the section where sulfuric acid is thermally decomposed to produce sulfur dioxide. The sulfur dioxide is used in the CEA section where it is combined with water and iodine to produce hydrogen iodide. GA is responsible for the process section where the hydrogen iodide is decomposed to produce hydrogen. The process sections are constructed on skids and are interconnected through a chemical storage skid. All chemicals used in the S-I cycle, with the exception of sulfur dioxide, are transferred to and from tanks located on the chemical storage skid. Because of concerns over its high toxicity, sulfur dioxide is not stored in the process and is transferred directly from the SNL skid to the CEA skid.

Phase I of the work involved the integrated operation of the three process section to demonstrate a complete S-I cycle. The results from initial integrated testing of the three sections are reported in the Sandia report titled "Results of Phase I Testing of the SulfurIodine Integrated Lab Scale Experiment" dated April 2008. Phase II of the work involves additional integrated testing and improvements of the process. Tasks completed in Phase II include significant improvements in each of the three process sections and continued integrated operation between process sections. Additionally, modifications to resolve problems encountered in the initial integrated testing were required. Several of these modifications have been significant and time consuming. However, for all three process sections, all major process modifications have been completed.

The hydrogen iodide decomposition section has undergone many process modifications and the process is routinely operated to produce hydrogen. The major improvements to the process include replacement of the hydrogen iodide decomposition reactor with a smaller unit. The initial unit was designed for production of $0-1000 \mathrm{~L} / \mathrm{hr}$ hydrogen. Because of its large size, considerable time was required for preheating the unit and for equilibrium to be established. The new smaller unit has been successfully operated multiple times and hydrogen has been produced up to $75 \mathrm{~L} / \mathrm{hr}$. The hydrogen iodide decomposition section is ready for additional integrated testing. During tests proceeding the integrated testing several process components suffered from $\mathrm{Ta}$ 
corrosion/embrittlement that resulted in their failure. The problem has been addressed by using modified operating conditions and periodic testing and replacement of certain equipment. Additionally, new designs for the equipment that experienced corrosion are being developed and the equipment constructed at this time.

For the hydrogen iodide production process or Bunsen process (CEA), the major tasks completed include the installation of a modified Bunsen reactor and modification of the process to transfer iodine from the chemical storage skid to the CEA process skid. The new Bunsen reactor contains small Raching rings to improve reactant contact and a differential pressure unit to aid in process control. For transferring iodine, a pressure differential between the supply tank and the Bunsen reactor will replace the initial design that utilized a small piston type pump. An orifice plate and a differential pressure transducer have been installed in the iodine transfer tubing to measure the iodine flow rate. The new transfer method has been successfully tested. In addition to the process improvements, additional integrated operation between the CEA process and SNL process has also been completed. At this time, all major process modifications to the CEA process have been completed and testing of the new Bunsen reactor will commence shortly.

The acid decomposition process section (SNL) has undergone several modifications to improve process efficiency and integrated operation. The most significant improvement is the installation of a backpressure regulator and buffer tank between the SNL section and the CEA section. In initial integrated testing, the outer tube of the acid decomposition unit cracked and had to be replaced. The cause of the failure was thermal shock caused by liquid chugging in the unit resulting in cool liquid contacting hot surfaces. The chugging was caused by pressure fluxuations from the cycling of a compressor used in the CEA process for compression of the sulfur dioxide gas once it was received from the SNL section. The new pressure control system has been successfully tested in integrated operation with the CEA process. Other modifications and improvements include modification of the acid concentrator used in the process for higher efficiency, installation of an acid neutralization process for the process cooling water and the development of a new and much more efficient method for construction of the acid decomposer unit. In stand-alone tests, the effect of acid decomposition temperature on decomposition efficiency was investigated. The results indicate, that under the conditions of the test ( 1 bar gauge, $41 \%$ acid), that acid decomposition begins to decrease at a temperature between $750^{\circ} \mathrm{C}$ and $800^{\circ} \mathrm{C}$. At $700^{\circ} \mathrm{C}$, gas production decreased by $50 \%$ and no gas was produced at $650^{\circ} \mathrm{C}$. 


\section{PROGRAM OBJECTIVES}

The major objectives in FY08 for Phase II work are:

- Integrated operations for the S-I cycle, including completion of initial integrated shakedown operations, control verification tests (interface skid operations, production rate tests, shutdown tests),

- Transient response tests (startup, shutdown, flow rate perturbations, mismatched flow rates), and cross talk tests (inter skid contamination and response).

- Process improvements or modifications as budgets permit. 



\section{PROCESS MODIFICATIONS AND TESTING}

Although Phase 1 operations were completed in April that resulted in a partially integrated run producing hydrogen, several hardware and materials issues were encountered that required extensive modifications to the Bunsen section and the HI decomposition section. During Phase II these modification were incorporated and stand alone testing was conducted.

\subsection{HYDROGEN IODINE PRODUCTION, BUNSEN REACTION (CEA)}

\subsubsection{Issues Identified From Initial Integrated Tests}

Based on the results from stand-alone tests and the initial integrated operation, it was determined that significant modification were required for the CEA hydrogen iodide production process. This included the installation of a modified Bunsen reactor and iodine pumping system.

In the CEA process section, sulfur dioxide, iodine and water are reacted to form sulfuric acid and hydrogen iodide. This is performed in the Bunsen reactor operating at $\sim 130^{\circ} \mathrm{C}$ and 4-6 bar. Sulfur dioxide and oxygen are received from the acid decomposition section and compressed and cooled to give liquid sulfur dioxide. The oxygen is vented and the sulfur dioxide is transferred to the Bunsen reactor along with iodine received from the GA hydrogen iodide decomposition section and water from the chemical storage skid. Sulfuric acid formed in the Bunsen reactor is recycled to the SNL acid decomposition section and hydrogen iodide is transfer to the GA hydrogen iodide decomposition section.

Significant issues identified during the initial integrated test that have been addressed in Phase II of the work include the need for more precise control over reactant flow rates, especially $\mathrm{I}_{2}$, mixing of reactants in the Bunsen reactor and process control of the Bunsen reactor. A key issue for successful operation of the Bunsen reactor is control over flow rate for the iodine stream. A major difficulty encountered has been pumping iodine from the chemical storage skid to the CEA skid. This was mainly due to iodine freezing in the tubing and a significant effort was made to improve heating and insulation of the iodine tank and transfer tubing. Another significant problem has been with the iodine pump. Because of the high density, high viscosity and high vapor pressure of liquid iodine and the very low flow rates used in this work locating a pump for iodine has been difficult. The initial method selected for pumping the iodine was to use a small ceramic piston pump. The pump was unsuccessful at pumping the iodine. The pumping problem has been mitigated by pressurizing the $I_{2}$ supply tank to $\sim 4-5$ bars and use the pressure difference between the supply tank and Bunsen reactor to transfer the iodine. 
The initial integrated test consisted of:

- Liquid $\mathrm{SO}_{2}$ is produced from the $\mathrm{O}_{2} / \mathrm{SO}_{2}$ gaseous mixture generated by the SNL acid decomposition process,

- Water and iodine are transferred from the chemical storage skid to the CEA skid,

- The three chemicals are injected into the Bunsen reactor,

- The light phase, $\mathrm{H}_{2} \mathrm{SO}_{4}$ and water, is returned to the chemical storage skid to be used in the SNL process,

- The $\mathrm{HI}_{\mathrm{x}}$ produced from the Bunsen reaction is collected in a glass vessel on the CEA skid for use in the GA hydrogen iodide decomposition process after chemical characterization.

For the initial integrated test, the $\mathrm{HI}_{\mathrm{x}}$ produced by the Bunsen reaction was collected in a glass bottle (Fig. 3.1) and stored for analysis. $\mathrm{H}_{2} \mathrm{SO}_{4}$ produced by the Bunsen reaction was collected in a density control cell placed on the CEA skid (Fig. 3.2).

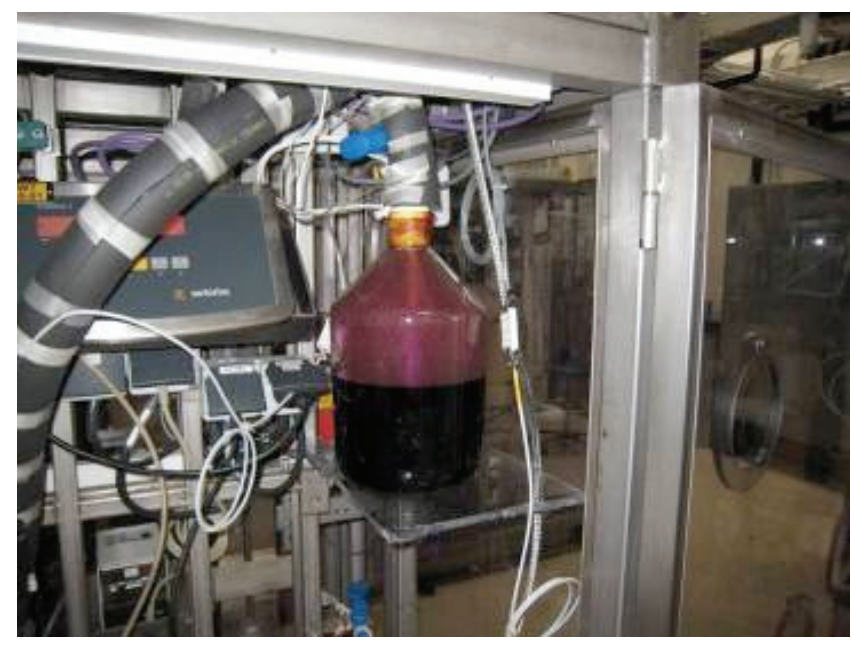

Figure 3.1 Collected in Skid 1 at the exit of the Bunsen reactor.

The apparatus was operated for more than one hour. The preliminary analyses on the collected Bunsen reactor products indicated:

- The heavy phase had a composition of $42 \mathrm{wt} \% \mathrm{HI}_{\mathrm{x}}, 10 \mathrm{wt} \% \mathrm{I}_{2}$ and $48 \% \mathrm{H}_{2} \mathrm{O}$. These values indicate some degree on non-ideality in the Bunsen reaction which is under investigation.

- The light phase had a density of $1.23 \mathrm{~g} / \mathrm{ml}$ after removal of the $\mathrm{I}_{2}$ and $\mathrm{HI}_{\mathrm{x}}$. If the Bunsen reactor is operating at maximum efficiency a values of 1.5 should be attained. The light phase also had an excess of $\mathrm{HI}$ and $\mathrm{I}_{2}$.

These results indicate that although the production of $\mathrm{HI}_{\mathrm{x}}$ did occur, the process was not optimal. Excess water was present in the both phases. 


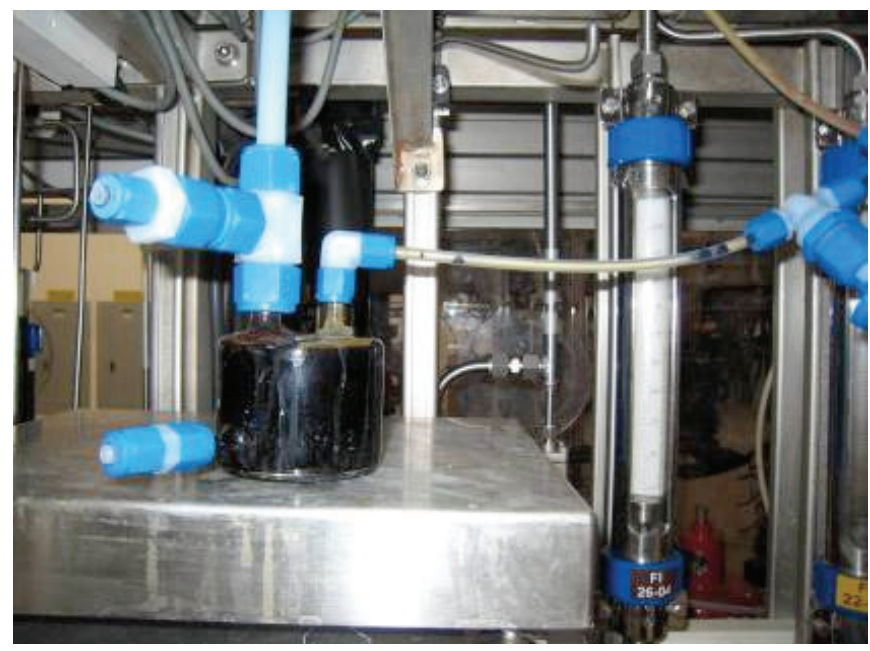

Figure $3.2 \mathrm{H}_{2} \mathrm{SO}_{4}$ collected online in the density control cell.

The samples collected during this integrated test were sent to the University of Nevada, Las Vegas (UNLV) who is responsible for the analyses of the samples. Three samples were collected, one of the lower $\mathrm{HI}_{\mathrm{x}}$ phase, and two for the upper light phase $\left(\mathrm{H}_{2} \mathrm{SO}_{4}\right)$, one during the test and one at the end of the test. The results obtained by UNLV are given in the Table 1 .

Table 1. Results from Analysis of Bunsen Reaction Products

\begin{tabular}{|c|c|c|c|c|c|c|c|c|c|}
\hline \multirow{3}{*}{ Sample } & \multicolumn{9}{|c|}{ Element Analyzed (in M.L ${ }^{-1}$ ) and Technique Used } \\
\hline & Total I & $\mathbf{I}^{-}$ & $\mathbf{I}_{2}$ & Total P & $\begin{array}{c}\text { Total } \\
\text { S }\end{array}$ & $\mathrm{H}_{2} \mathrm{SO}_{4}$ & $\mathrm{SO}_{2}$ & $\begin{array}{c}\text { Volumetric } \\
\text { Mass } \\
\text { (g/L) }\end{array}$ & $\mathbf{H}_{2} \mathbf{O}$ \\
\hline & $\begin{array}{l}\text { ICP- } \\
\text { AES }\end{array}$ & IC & Calc. & $\begin{array}{l}\text { ICP- } \\
\text { AES }\end{array}$ & $\begin{array}{l}\text { ICP- } \\
\text { AES }\end{array}$ & IC & Calc. & Densimeter & Calc. \\
\hline $\mathrm{HI}_{\mathrm{x}}$ & 4.525 & 3.415 & 0.555 & $<\mathrm{LDD}$ & 1.216 & 1.117 & 0.099 & 1413.580 & 40.231 \\
\hline $\mathrm{H}_{2} \mathrm{SO}_{4}$ & 0.060 & 0.000 & 0.030 & 0.000 & 4.181 & 3.690 & 0.491 & 1237.080 & 48.195 \\
\hline $\begin{array}{l}\mathrm{H}_{2} \mathrm{SO}_{4} \\
\text { end test }\end{array}$ & 7.045 & 4.708 & 1.169 & 0.013 & 0.818 & 0.757 & 0.06 & 1566.310 & 32.818 \\
\hline
\end{tabular}

$\mathrm{I}_{2}$ was calculated using the difference between total $\mathrm{I}$ and iodide $\mathrm{I}^{-} \cdot \mathrm{SO}_{2}$ was calculated using the difference between total $\mathrm{S}$ and $\mathrm{H}_{2} \mathrm{SO}_{4}$ obtained from the analysis of the sulfate in the mixture. $\mathrm{H}_{2} \mathrm{O}$ was calculated from the sample density and the molecular masses of $\mathrm{HI}, \mathrm{I}_{2}, \mathrm{H}_{2} \mathrm{SO}_{4}$ and $\mathrm{H}_{3} \mathrm{PO}_{4}$. The $\mathrm{H}_{3} \mathrm{PO}_{4}$ is a contaminant in water transferred from the GA process to the CEA process. The $\mathrm{H}_{2} \mathrm{SO}_{4}$ phase shows the presence of $0.3 \mathrm{M}$ iodine and $0.5 \mathrm{M}$ sulfur. These were attributed to residual $\mathrm{SO}_{2}$ in the sample. No solid sulfur was detected.

The presence of iodine in this phase can be attributed to its intrinsic solubility, and the presence of $\mathrm{SO}_{2}$ to the fact that the injected $\mathrm{SO}_{2}$ did not completely react. 
The amount of water in each phase is much higher than expected if the Bunsen reactor was operating optimally. This could be due to insufficient $\mathrm{I}_{2}$ and/or $\mathrm{SO}_{2}$ being introduced into the Bunsen reactor or too much water. The high iodine content of the $\mathrm{H}_{2} \mathrm{SO}_{4}$ phase at the end of the test shows that the reaction most likely stopped due to an excess of water and/or a lack of $\mathrm{SO}_{2}$. This is also indicated by a decrease in temperature in the Bunsen reactor. Significant amounts of $\mathrm{H}_{2} \mathrm{SO}_{4}$ and $\mathrm{SO}_{2}$ were in the $\mathrm{HI}_{\mathrm{x}}$ phase. This is likely due to a dragging phenomenon through the HI exit, but nevertheless shows that $\mathrm{H}_{2} \mathrm{SO}_{4}$ was present at the bottom of the column, and that $\mathrm{SO}_{2}$ reacts immediately when introduced into the Bunsen reactor. The HI phase is very dilute. But, it does not contain the amount of iodine expected from the stoichiometry of the Bunsen reaction. This might be explained by the fact that the tubing used to collect the heavy phase actually goes inside the Bunsen reactor approximately two inches resulting in collection of a sample at the top part of the heavy phase. Because of higher density of iodine compared to the other mixture components, most of the iodine is likely at the bottom of the reactor.

In summary, the Bunsen reaction did occur in the reactor during the integrated test leading to the production of $\mathrm{a}_{2} \mathrm{SO}_{4}$ and a $\mathrm{HI}_{\mathrm{x}}$ phase. However, the composition of the phases is not the one expected from the Bunsen reaction stoichiometry. This indicates better control over the flow rate of reactants into the Bunsen reactor is needed along with better control over phase separation in the reactor. In order to accomplish better control, several modifications have been made to the Bunsen reactor as well as on the iodine feeding line during the last months.

\subsubsection{Process Modifications}

In order to monitor the light phase composition, it was decided to install a set of differential pressure cells (DP cells) in the upper part of the Bunsen reactor. This set of DP cells that measure the pressure difference between two points in the reactor, will allow the determination of the average density of the liquid phase between those two points. The reactant flow rates can be adjusted to control the reactor operation. A new reactor upper section has been designed, constructed and installed that is equipped with two side ports for installation of a DP cell system. A drawing of this new upper part of the Bunsen reactor is given Fig. 3.3. 


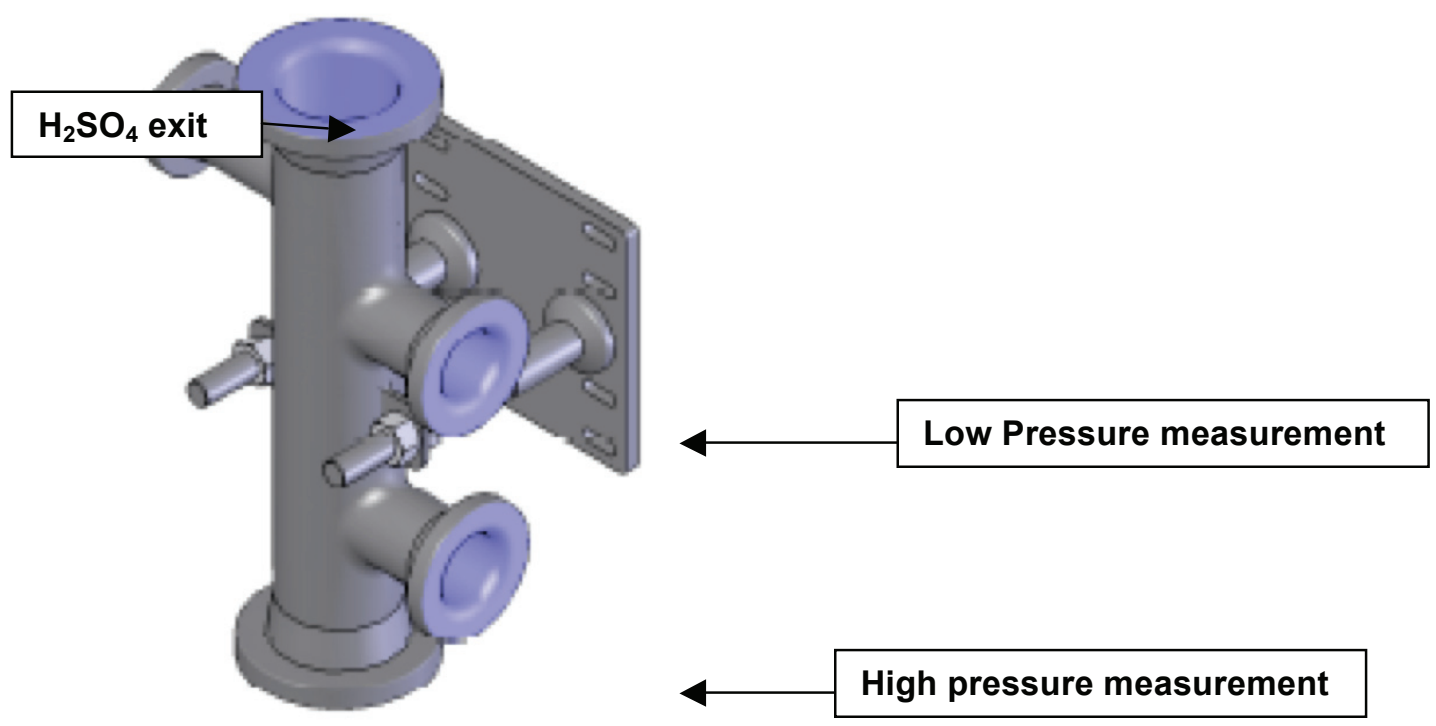

Figure 3.3 Schematic of the new upper part of the Bunsen reactor.

The difference in pressure between the two ports is a function of the liquid density and distance between the ports. The average density of the liquid can be determined using the following equation:

$$
\Delta P=\rho \times g \times H \text { or } \rho=\frac{\Delta P}{g \times H}
$$

where $\Delta \mathrm{P}$ in $\mathrm{mBar}$

$\rho$ in $\mathrm{g} . \mathrm{cm}^{-3}$

$\mathrm{H}$ in $\mathrm{mm}$.

The new reactor part was successfully tested with water at $120^{\circ} \mathrm{C}$ and 3 bars. The DP cells were calibrated during the water test. The density of the liquid in the reactor was varied by adding different amounts of glycol.

It has been previously stated that $\mathrm{H}_{2} \mathrm{SO}_{4}$ and $\mathrm{SO}_{2}$ were observed in the $\mathrm{HI}_{\mathrm{x}}$ phase. This indicates that $\mathrm{SO}_{2}$ reacts immediately upon being injected into the reactor and that it was injected too close to the $\mathrm{HI}_{\mathrm{x}}$ exit. Alternatively, $\mathrm{SO}_{2}$ was also found in the light $\mathrm{H}_{2} \mathrm{SO}_{4}$ phase. This indicates that part of the injected $\mathrm{SO}_{2}$ did not react before it could reach the top of the reactor. This later phenomenon can be explained by the formation of relatively large bubbles of $\mathrm{SO}_{2}$ at the point of injection. The Bunsen reaction takes place on outer surface of $\mathrm{SO}_{2}$ bubble as they travels up the column. If the $\mathrm{SO}_{2}$ bubbles are too large, the bubbles may reach the top of the reactor before having completely reacted.

Two measures were implemented to maintain $\mathrm{SO}_{2}$ in the central section of the Bunsen reactor. The injection point of $\mathrm{SO}_{2}$ was set $4 \mathrm{in}$. above its previous value to ensure no $\mathrm{H}_{2} \mathrm{SO}_{4}$ could form close to the $\mathrm{HI}$ exit and a 4 in. high stack of Raschig rings was placed inside the reactor just above the $\mathrm{SO}_{2}$ injection point to break any large $\mathrm{SO}_{2}$ bubbles into 
smaller ones. A schematic diagram of the new geometry of the Bunsen reactor is given Fig. 3.4.

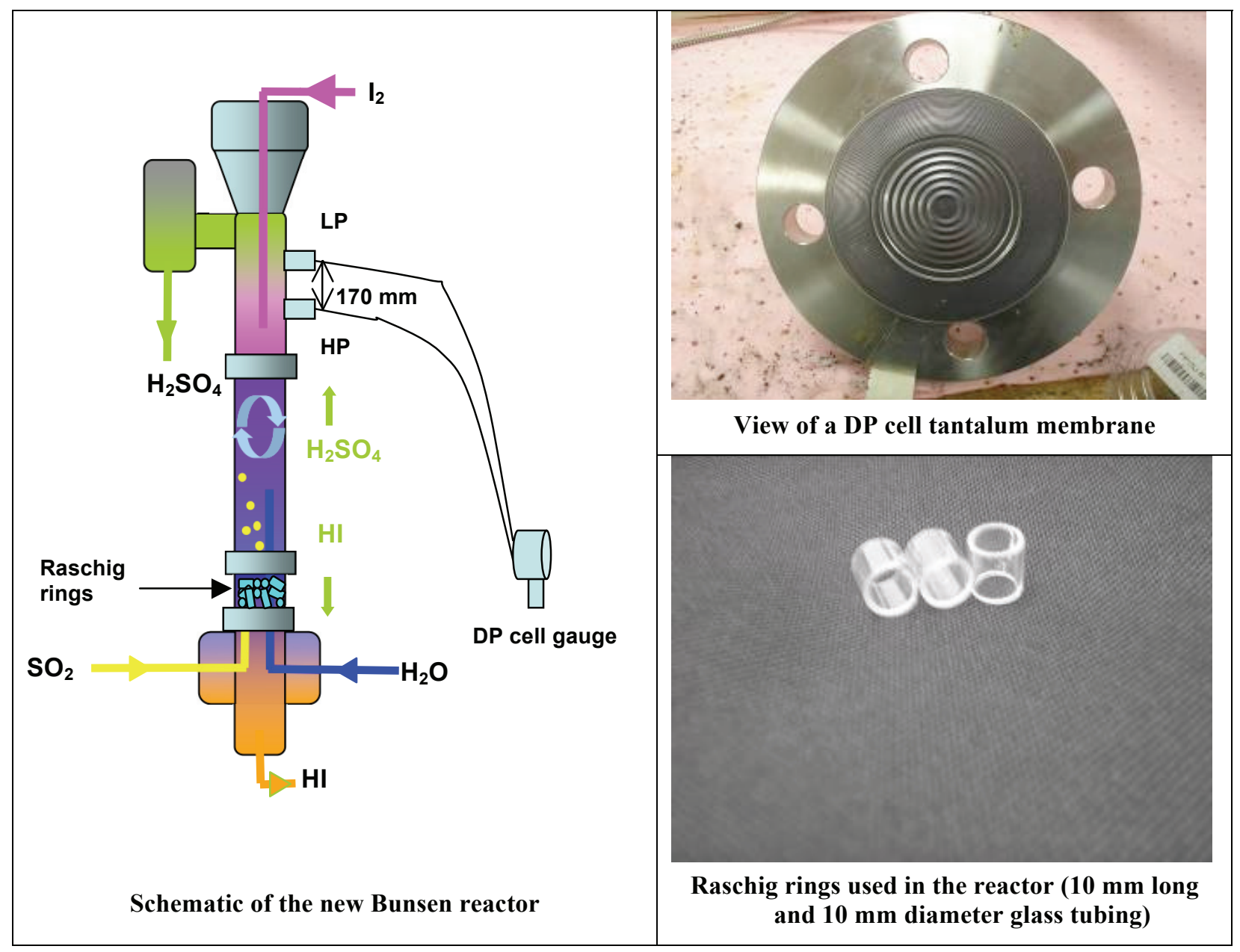

Figure 3.4. Schematic of the Bunsen reactor with DP cells and Raschig rings.

After implementing the Bunsen reactor changes, a new series of tests were performed. Unfortunately, all attempts to pump iodine from the chemical storage skid to the Bunsen reactor were unsuccessfully. This was because of problems with corrosion, leaking fittings, breakage of the iodine pump and leaks at the $\mathrm{HI}_{\mathrm{x}}$ pump due to a corrosion of the end fittings. This latter problem was caused by stray currents from a poorly insulated heat trace. It was finally acknowledged that the piston type FMI pump being used was not suitable for iodine under our conditions of operation and another method must be used to transfer iodine to the Bunsen reactor.

It was decided to transfer iodine to the Bunsen reactor by pressurizing the iodine storage tank on the chemical storage skid to 4-5 bars, a pressure higher than that of the Bunsen reactor. To monitor and control the iodine flow rate a calibrated orifice (0.06 in. diameter) was installed in the tubing and a differential pressure cell with tantalum 
diaphragms was used to determine the pressure drop across the orifice plate for calculating the iodine flow rate. The modified system is shown in Fig. 3.5.
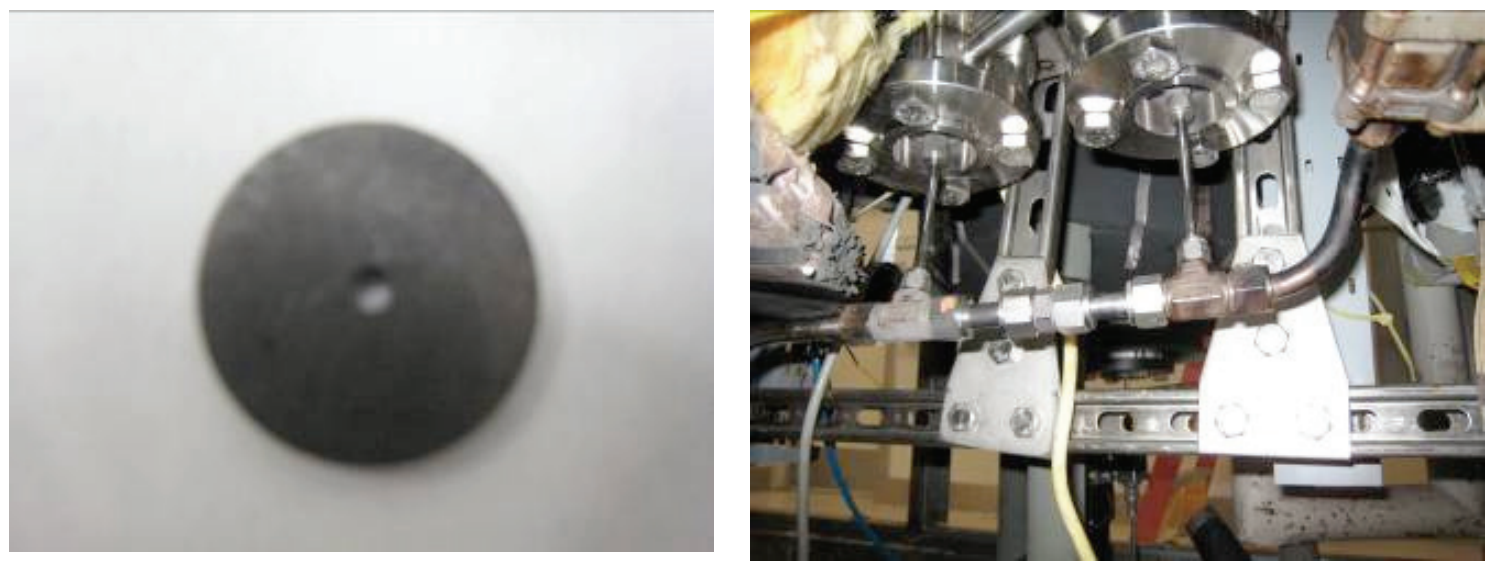

Figure 3.5. Calibrated orifice and view of the system with the two DP cells.

Using measurements from the DP cell installed in the new system, the iodine flow rate can be calculated using Bernoulli's relation of energy conservation given by:

$$
\mathrm{P}+\rho g z+1 / 2 \rho \mathrm{V}^{2}
$$

that remains constant along the flow path and in particular when going from the pipe through the calibrated orifice. P the pressure in the flow line, $\rho$ the fluid density, and $V$ is the speed of the liquid. The Bernoulli's equation can be used to calculate the flow rate using the pressure differential across the orifice plate.

Several other components have also been replaced including valves, heating tapes and the back-pressure regulator located on the $\mathrm{H}_{2} \mathrm{SO}_{4}$ exit stream of the Bunsen reactor. The backpressure regulator is being replaced with a low $\mathrm{C}_{\mathrm{v}}$ tantalum valve controlled by a pressure gauge.

\subsubsection{Summary: CEA Bunsen Section}

Issues identified in the initial integrated test and additional stand-alone tests have led to major modifications of major process equipment in the CEA hydrogen iodide process. These include installation of a modified Bunsen reactor for better mixing and process control and the modification of the iodine pumping system. The modified Bunsen reactor has been tested with a sulfur dioxide-water mixture and is now ready for additional standalone and integrated testing. The new iodine pumping system, using a pressure differential between the storage tank and Bunsen reactor, has been successfully tested.

\subsection{SULFURIC ACID DECOMPOSITION (SANDIA NATIONAL LABORATORIES)}

Sandia National Laboratories is responsible for the acid decomposition section of the S-I process. The process consists of two main processing steps: concentration of sulfuric 
acid received from the CEA process section and sulfuric acid decomposition to form sulfur dioxide, water and oxygen. Water is removed by condensation from the product stream and the sulfur dioxide and oxygen are transferred to the CEA process section. Over the past five months modifications to the process have been completed and tests have been performed in the stand-alone and integrated modes.

\subsubsection{System Modifications and Maintenance}

Several modifications have been completed for the SNL acid decomposition process. These include the installation of an acid neutralization step for the process cooling water, modification of the acid concentrator for more efficient operation and the addition of a pressure regulating system for integrated operation with the CEA process section. The acid decomposition section has been operated five times over the past five months. Two of the tests involved integrated operation with the CEA process section. In the last standalone test, the efficiency of acid conversion as a function of decomposition temperature was determined. Additionally, a new method has been developed to assemble the heat exchanger tubes and catalyst of the acid decomposer. The new method is significantly faster and far less tedious than the previously used method.

The circulating water chiller (Remcor, Inc.) is used to provide cooling water to the process condensers and acid decomposer manifold. The unit is periodically inspected and in the last inspection it was discovered that the cooling water contained significant amounts of corrosion products. The chiller and all tubing that supply cooling water were flushed multiple times until no further corrosion products were detected. The cooling water is not in direct contact with any acid, sulfur dioxide or any other corrosive compounds used in the acid decomposition process. It was determined that corrosion was caused by contamination of the cooling water with sulfur dioxide. The sulfur dioxide entered the cooling water by permeating through PTFE tubing used in the construction of the processes water chilled condensers. To prevent any further corrosion, an acid neutralization step was added to the cooling system. This consisted of a vessel filled with pieces of magnesium hydroxide followed by a Teflon filter, both placed at the entrance to the water chiller. The magnesium hydroxide neutralizes any sulfur dioxide in the cooling water.

The acid concentrator was modified to increase the efficiency of the unit. This was necessary to increase the capacity of the unit for concentrating undecomposed acid collected at the exit of the acid decomposer for recycle in addition to fresh 20 mole \% acid supplied by the CEA Bunsen section. The concentrator was initially designed for concentration of the acid received from the CEA Bunsen section only. It was believed the recycle acid could be mixed with the fresh feed acid and fed to the decomposer. However, because of the high efficiency of the acid decomposer, the acid for recycle is only 6-9 mole \% acid and needs to be concentrated. The acid concentrator is a falling film type of unit operated under vacuum. It consists of a heated silicon carbide tube with a Teflon piece inserted in the center. Acid travels down the annular space between the silicon carbide tube and the Teflon piece. The outer surface of the silicon carbide tube is heated with ceramic fiber heaters. The center Teflon piece has $\mathrm{V}$-shaped spiral grooves cut into the surface to slow the passage of acid through the concentrator and continuously 
direct the acid against the heated walls of the silicon carbide tube. To increase the capacity of the concentrator for processing the additional recycle acid, a more powerful vacuum pump was installed along with modification of the center Teflon piece. The new vacuum pump allows for operation down to 0.1 psia with a flow rate of $60 \mathrm{~L} / \mathrm{hr}$ as apposed to the previous unit that operated at 0.5 psia and a flow rate of $30 \mathrm{~L} / \mathrm{min}$. The center Teflon piece was replaced with a new Teflon piece with much smaller and more tightly spaced grooves. In testing, 20 mole $\%$ acid was concentrated to 46 mole \%. Previously acid could only be concentrated to $\sim 42$ mole $\%$. Testing was also performed with an equal volume mixture of 7 mole $\%$ acid collected in the process recycle tanks and fresh 20 mole \% acid. The acid was concentrated to 42 mole $\%$ operating at $190^{\circ} \mathrm{C}$ and $0.1-0.2$ psia.

Can we insert a picture of the skid — with pointers to the modified components??

During the initial integrated operation of the S-I process the outer tube of the acid decomposer, constructed of silicon carbide, cracked due to thermal shock from liquid acid chugging in the decomposer. This occurred because of pressure fluxuations in the sulfur dioxide transfer line caused by cycling of the compressor used in the CEA Bunsen process to compress sulfur dioxide. The sudden decrease in pressure resulted in relatively cool acid $\left(200^{\circ} \mathrm{C}\right)$ in the lower section of the acid concentrator contacting the upper wall of the unit at $400^{\circ}-500^{\circ} \mathrm{C}$. To prevent this problem, a backpressure regulator and a $2 \mathrm{~L}$ pressure buffering tank were installed in the sulfur dioxide transfer stream between the SNL section and the CEA section. The backpressure regulator maintains a constant pressure in the acid decomposition process regardless of the down stream pressure. The buffer tank holds sufficient sulfur dioxide to dampen out pressure fluxuations caused by the compressor. The system has been successfully tested several times while operating integrated with the CEA section.

In addition to the process modifications and process testing, routine maintenance operations have been performed including replacement of o-ring seals and Teflon pump seals, recalibration of sulfur dioxide monitors and pressure transducers, and replacement of the oxygen monitor used in the process to determine the ratio of sulfur dioxide to oxygen in the production stream.

A new method has been developed to assemble the heat exchanger tubes and catalyst used in the acid decomposer. The previous method involved individually loading the catalyst pellets one by one into the annular space between the inner and out tubes while slowly sliding the inner tube into the outer tube. The process was very tedious, time consuming and often resulted in breaking the inner tube. The new method utilizes a polyethylene tube to secure the catalyst pellets to the inner heat exchanger tube. The tube is placed over the upper section of the heat exchanger tube and the catalyst pellets are poured into the annular space. A picture showing the catalyst pellets secured to the inner heat exchanger tube with the polyethylene tube is shown in Fig. 3.6. The inner tube with catalyst is easily placed inside the outer heat exchanger tube. Once the unit is heated with air being passing through the acid decomposer, the polyethylene tube decomposes to form carbon dioxide and water. The catalyst pellets remaining in the upper section of the tube assembly. 


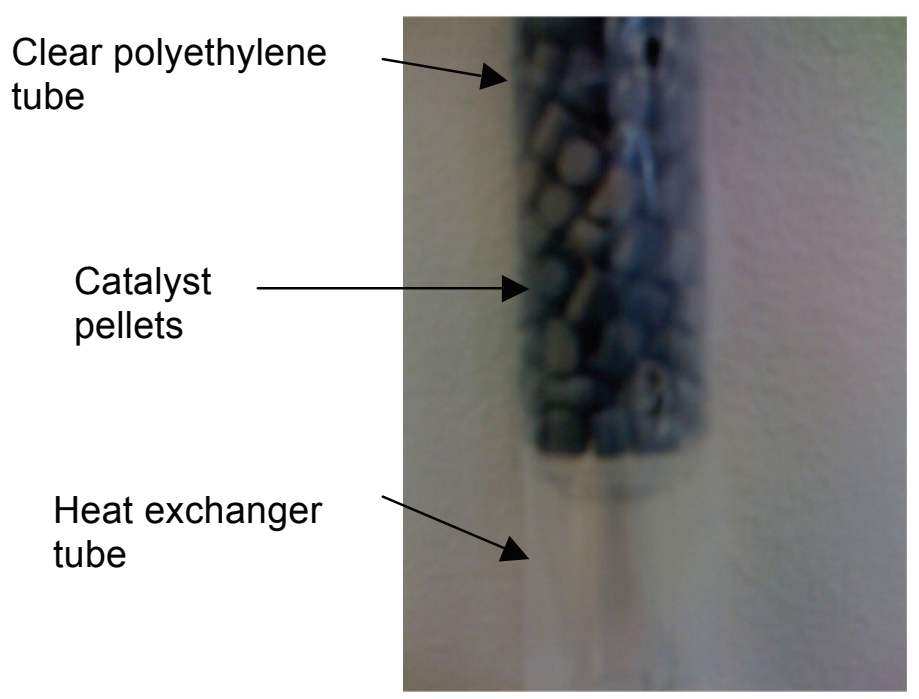

Figure 3.6. Inner decomposer tube showing catalyst pellets secured to tube with a sheet of polyethylene.

\subsubsection{System Operation}

The SNL acid decomposition process has been operated five times over the past five months, three times in stand-alone mode and twice while integrated with the CEA process section. Two of the stand-alone tests were to verify proper process operation after completion of process modifications. The two integrated tests with the CEA section involved production of sulfur dioxide and subsequent transfer to the CEA skid. The tests were successful and no problems were encountered. In the third stand-alone test, the effect of decomposition temperature on acid decomposition efficiency was determined. Table 2 gives the operational parameters for the test. All tests were performed at a pressure of 2 bar absolute with 41 mole $\%$ acid. The results from varying the decomposition temperature from $650^{\circ}$ to $850^{\circ} \mathrm{C}$ are given in Table 3 . The results indicate operation at $800^{\circ}-850^{\circ} \mathrm{C}$ give approximately the same conversion of acid. At $750^{\circ} \mathrm{C}$ the production of sulfur dioxide starts to decrease and at $700^{\circ} \mathrm{C}$ the product gas flow rate has decreased by $\sim 50 \%$. No gas was produced at $650^{\circ} \mathrm{C}$. The data indicate for maximum conversion under the conditions of the test the acid decomposer must be operated at $800^{\circ} \mathrm{C}$ or higher. 
Table 2. Operational Parameters for Temperature Dependence Testing

\begin{tabular}{ll}
\hline $\begin{array}{l}\text { Acid Concentrator } \\
\text { Operational Parameters }\end{array}$ & \\
\hline $\begin{array}{l}\text { Input acid concentration to } \\
\text { acid concentrator }\end{array}$ & 20 mole $\%$ \\
$\begin{array}{l}\text { Acid concentrator operating } \\
\text { temperature and pressure }\end{array}$ & $190^{\circ} \mathrm{C}$, \\
$\begin{array}{l}\text { Output acid concentrator } \\
\text { acid concentration }\end{array}$ & 41 mole $\%$ \\
& \\
Acid Decomposer & \\
Operational Parameters & \\
Acid feed concentration & 41 mole $\%$ \\
Decomposition pressure & 2 bar abs. \\
\hline
\end{tabular}

Table 3. Results for Temperature Effect on Decomposition Efficiency

\begin{tabular}{ccc}
\hline $\begin{array}{c}\text { Acid Decomposition } \\
\text { Temperature }\left({ }^{\circ} \mathbf{C}\right)\end{array}$ & $\mathbf{O}_{2} / \mathbf{S O}_{2}$ Ratio & $\begin{array}{c}\text { Gas }\left(\mathbf{S O}_{\mathbf{2}}+\mathbf{O}_{2}\right) \\
\text { Flow Rate }(\mathbf{L} / \mathbf{h r})\end{array}$ \\
\hline 850 & 0.48 & $2.4 \pm 0.1$ \\
800 & 0.5 & $2.2 \pm 0.1$ \\
750 & 0.47 & $1.8 \pm 0.1$ \\
700 & 0.56 & $1.1 \pm 0.2$ \\
650 & $\mathrm{No} \mathrm{SO}_{2}$ produced & 0 \\
\hline
\end{tabular}

\subsubsection{Summary: SNL Acid Decomposition Section}

Several modifications to the SNL acid decomposition process for increased efficiency, corrosion control and better process control have been completed. The acid concentrator has been modified for processing recycle acid in addition to acid supplied by the CEA process. An acid neutralization process, using magnesium hydroxide, has been added to the cooling water system to prevent corrosion of the system circulating water chiller. The results from initial integrated operation indicated that the pressure in the acid decomposer must be controlled to prevent liquid chugging resulting in thermal shock and breakage of the unit's heat exchanger tubes. A backpressure regulator and buffer tank has been installed and the modified system has been successfully tested multiple times. The acid decomposition process has been successful operated three times in the stand-alone mode and twice in the integrated mode in the past five months. The acid decomposition process is ready for additional integrated testing. In stand-alone tests it has been determined that for operation of the acid decomposer at a pressure of 2 bar absolute, a decomposition temperature of $800^{\circ} \mathrm{C}$ or greater is required for maximum acid decomposition. 


\subsection{HI Decomposition Section Development (General Atomics)}

\subsubsection{Introduction/Objectives}

The $\mathrm{HI}$ decomposition skid takes the $\mathrm{HI}_{\mathrm{x}}$ feed (2:8:10 molar ratios of HI:Iodine:Water) from Section 1 and first removes the iodine in a liquid-liquid extraction process utilizing phosphoric acid. HI is distilled from the remaining water-phosphoric acid solution and delivered to the reactor for decomposition to $\mathrm{I}_{2}$ and $\mathrm{H}_{2}$. As the reaction is limited to a $20 \%$ conversion thermodynamically, the unreacted HI must be separated and recycled in order to reach the desired $\mathrm{H}_{2}$ production rates. Initially both reactive and extractive distillation processes were evaluated. Based on experimental results, extractive distillation was selected as the HI distillation approach for the ILS experiment. The objectives of the extractive distillation demonstration were to construct a system capable of withstanding the highly corrosive chemicals, at a hydrogen production of $100 \mathrm{~L} / \mathrm{hr}$ or greater, and demonstrate extraction of $\mathrm{HI}$ and $\mathrm{H}_{2} \mathrm{O}$ from a $\mathrm{HI}_{\mathrm{x}}$ solution, and distillation of HI for subsequent reaction.

The Phase II testing of the Section 3 ILS equipment has involved a set of system modifications to improve reliability and responsiveness to experimental conditions as well as perform a series of routine experiments, which explore the parameter space of operations.

\subsubsection{System Modifications}

Reactor Retrofit. As Phase I operations concluded at the end of March, a number of system modifications were identified as necessary to improve the reliability and over all operations of the HI decomposition process.

The decomposition reactor, which was originally sized for $>1000 \mathrm{~L} / \mathrm{hr}$ production of $\mathrm{H}_{2}$ turned out to be difficult to operate. The reactor was constructed from a 6-in. diameter tube, 50 in. long, and was packed with $4 \mathrm{~mm}$ activated carbon pellets. The result was a reactor that required considerable time to pre-heat. Activated carbon also has a finite adsorption of $\mathrm{HI}$, even at $450^{\circ} \mathrm{C}$. This resulted in a considerable run time required to reach equilibrium in the reactor.

A new reactor was designed and constructed with a 2-in. diameter, 50 in. length, and was installed in parallel to the old reactor as shown in Fig. 3.7. In addition to reducing the size of the reactor, the heaters were redesigned to provide more even heating. Originally, five 1250-watt band heaters were used on the $6 \mathrm{in}$. vessel, which resulted in slow, uneven heating of the reactor. The new design incorporates four 2500-watt clamshell heaters. This new reactor had a much faster heat up time as shown in Figs. 3.8 and 3.9. 


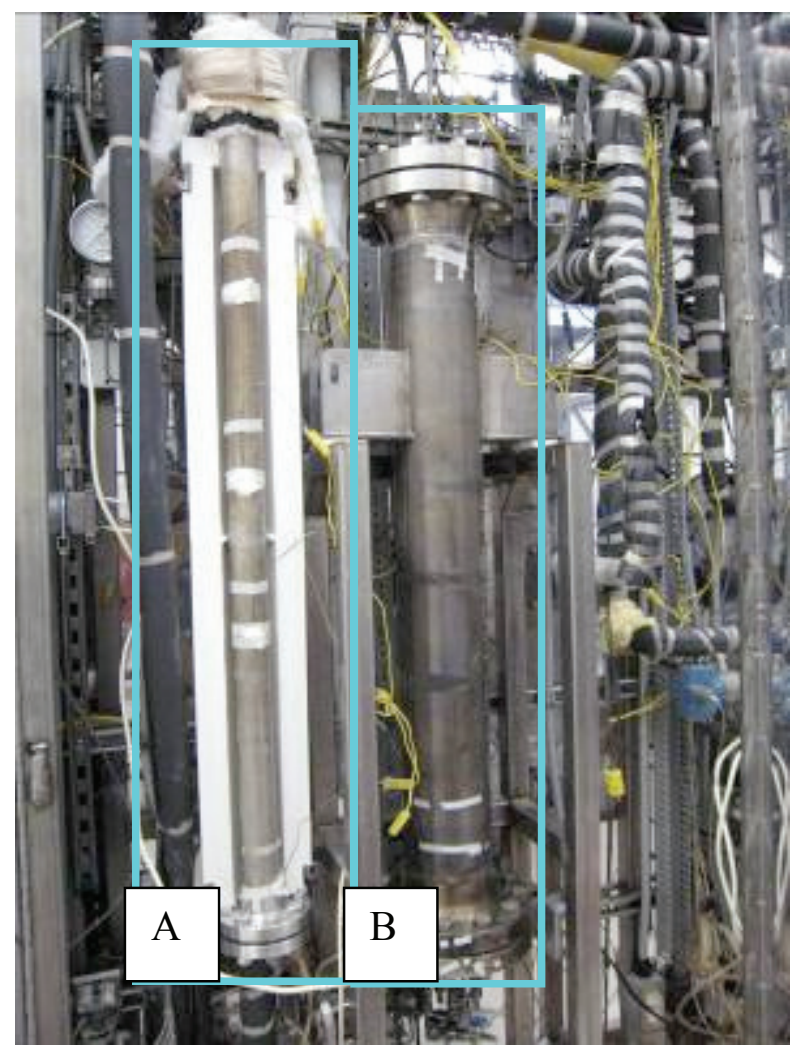

Figure 3.7. (a) New 2-in. diameter reactor vessel (b) Old 6-in. diameter reactor vessel.

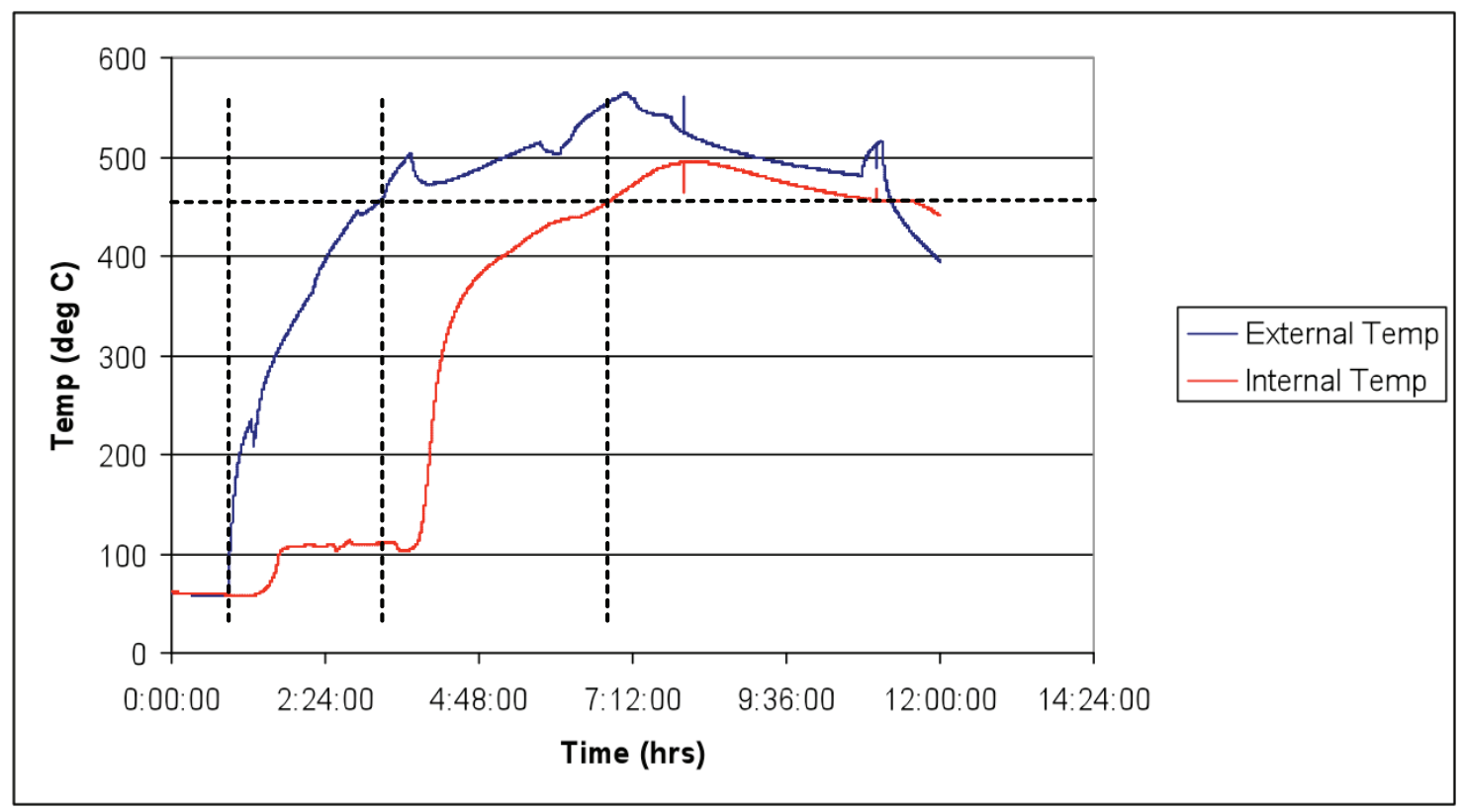

Figure 3.8. Representative heat up time for 6-in. diameter reactor. 


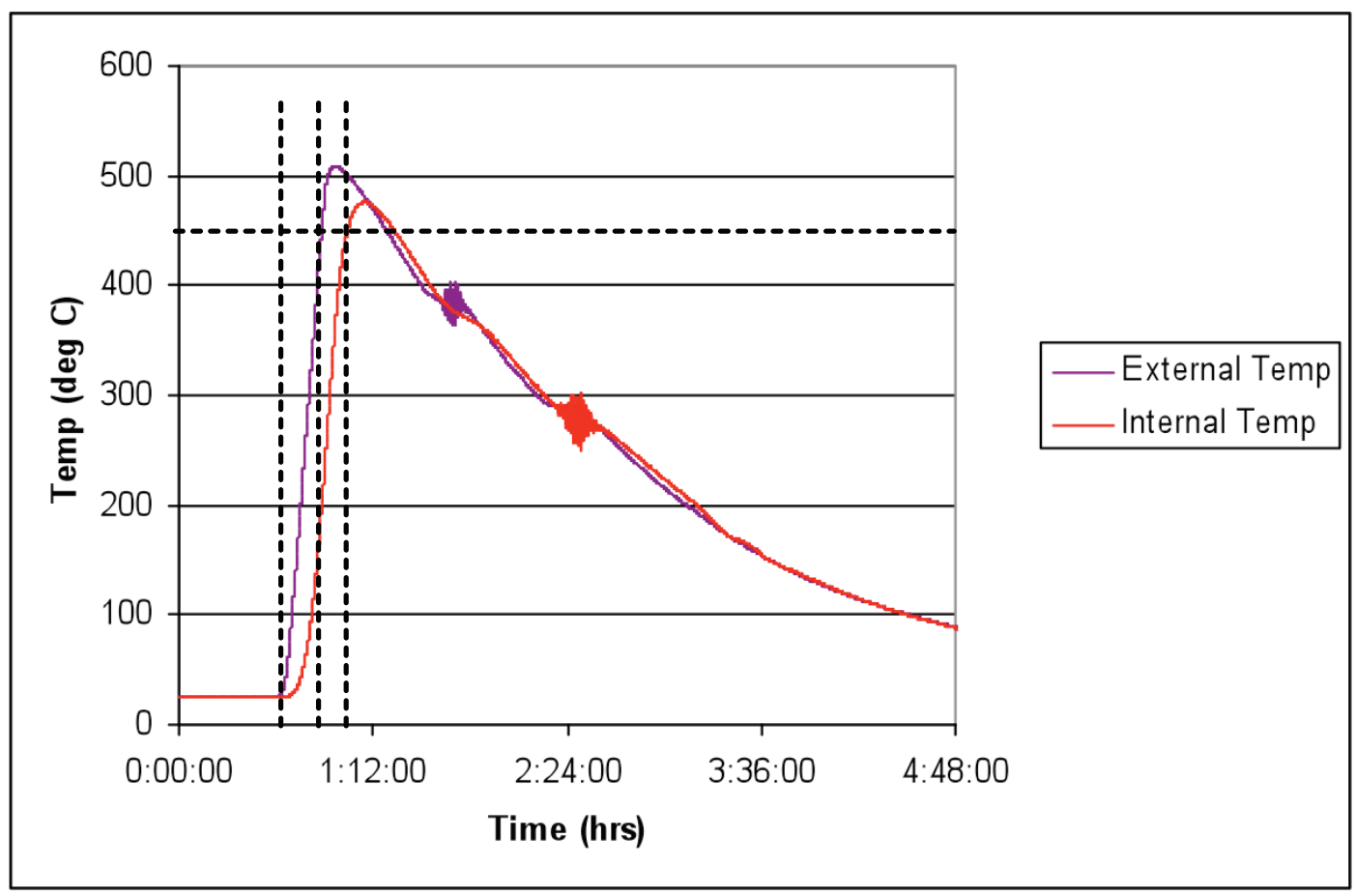

Figure 3.9. Representative heat up time for 2-in. diameter reactor.

Table 4 summarizes the heat up times for the two reactor designs. The response time in the 2-in. reactor vessel is dramatically improved by the smaller diameter and the enhanced heater design.

Table 4. Reactor Heating Times

\begin{tabular}{|c|c|c|}
\hline $\begin{array}{c}\text { Reactor } \\
\text { Diameter (in.) }\end{array}$ & $\begin{array}{c}\text { External } \\
\text { Temperature } \mathbf{4 5 0}^{\circ} \mathbf{C}\end{array}$ & $\begin{array}{c}\text { Internal Temperature } \\
\mathbf{4 5 0}^{\circ} \mathbf{C}\end{array}$ \\
\hline 6 & $2: 16$ & $5: 49$ \\
\hline 2 & $0: 16$ & $0: 25$ \\
\hline
\end{tabular}

Miscellaneous Subsystems. In addition to the reactor modifications, a number of minor system improvements were implements. In order to enhance the process fluid flows, additional self-regulating heat trace circuits and lines were added. Specifically, those streams with high iodine concentrations were traced in addition to any process valve on these lines.

Representative Data. As the system has been operated in a more routine fashion, the reliability of the sensor measurements and data obtained increased. This data allows for a better understanding of the operating parameters and allows for better control of the system.

Differential Pressure Units. Differential pressure cells are one of the key diagnostic controls on the system, providing liquid level, fluid density and flow rate information. 
The initial hardware purchased was defective, and incapable of dealing with the operating pressure. After selecting a different manufacturer, all differential pressure cells on the system were replaced with Rosemount units. These units have performed very well, producing reliable readings. A sample of the type of data obtained from these units is shown in Fig. 3.10.

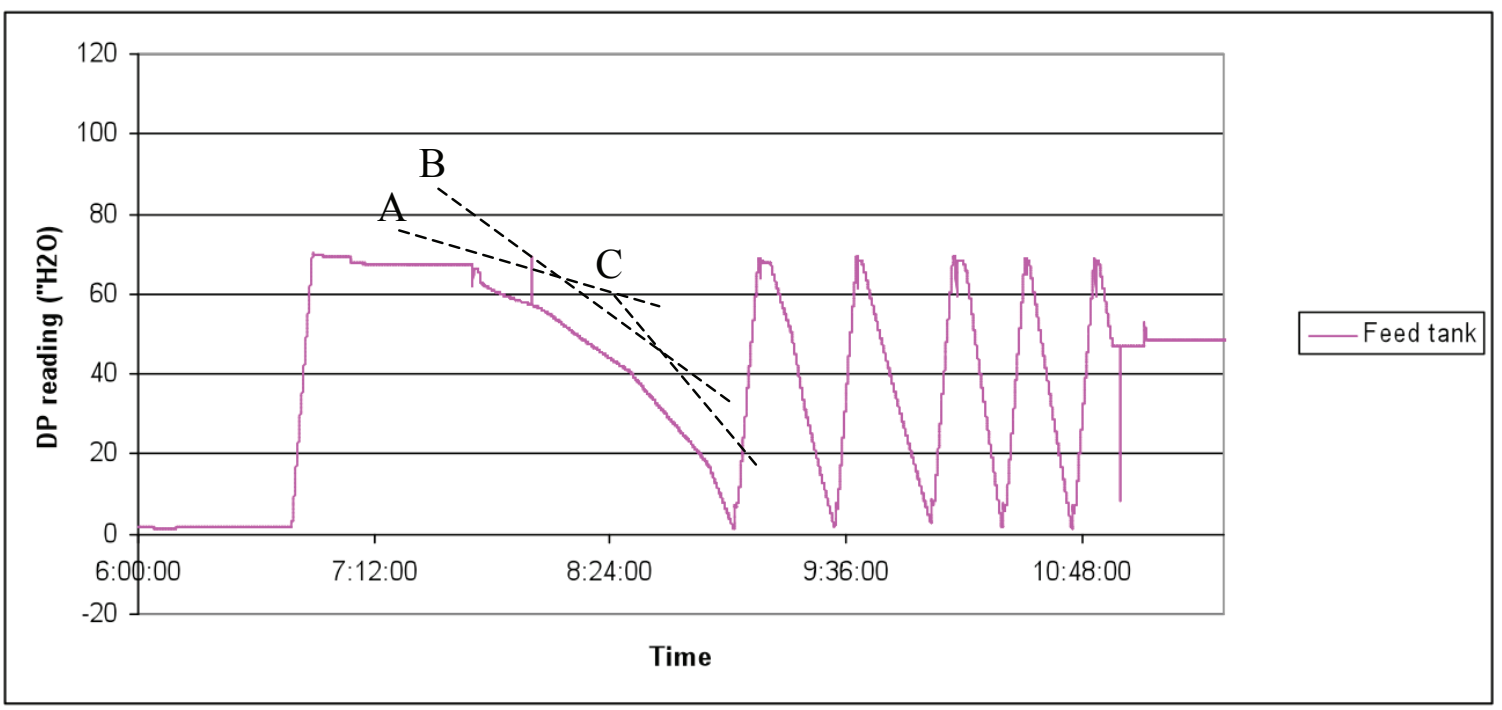

Figure 3.10. Typical feed tank DP readings for a run.

The three asymptotes displayed in Fig. 3.10 (A, B, and C) illustrate the ability to calibrate the system online. The slope of the plot can be used to determine the flow rate in real time, as it correlates to the pump settings. In this case a three-point calibration was performed prior to initiating the run. The reproducibility of the trace over each successive cycle of filling and emptying, which also includes cycling the pressure between 0-100 psig, is what makes these devices so useful in this application.

Distillation Column Performance. Figure 3.11 shows a typical temperature profile of the HI distillation column during operation. The data plotted consists of the liquid temperature in the boiler, measured by thermocouple inside a thermowell in the column, and the various temperatures along the upper portion of the distillation column (TT_213A-G). As the graph shows, the initial boiling point can be determined by the increase in temperature in the upper section of the column, due to the heat being transported by the vapor as well as the leveling off of the boiler temperature. The dip in the temperatures at Point $\mathrm{A}$, shows the beginning of flow into the column. The temperatures quickly recover and the column begins to function, moving towards steady state and eventual shut down at Point B. 


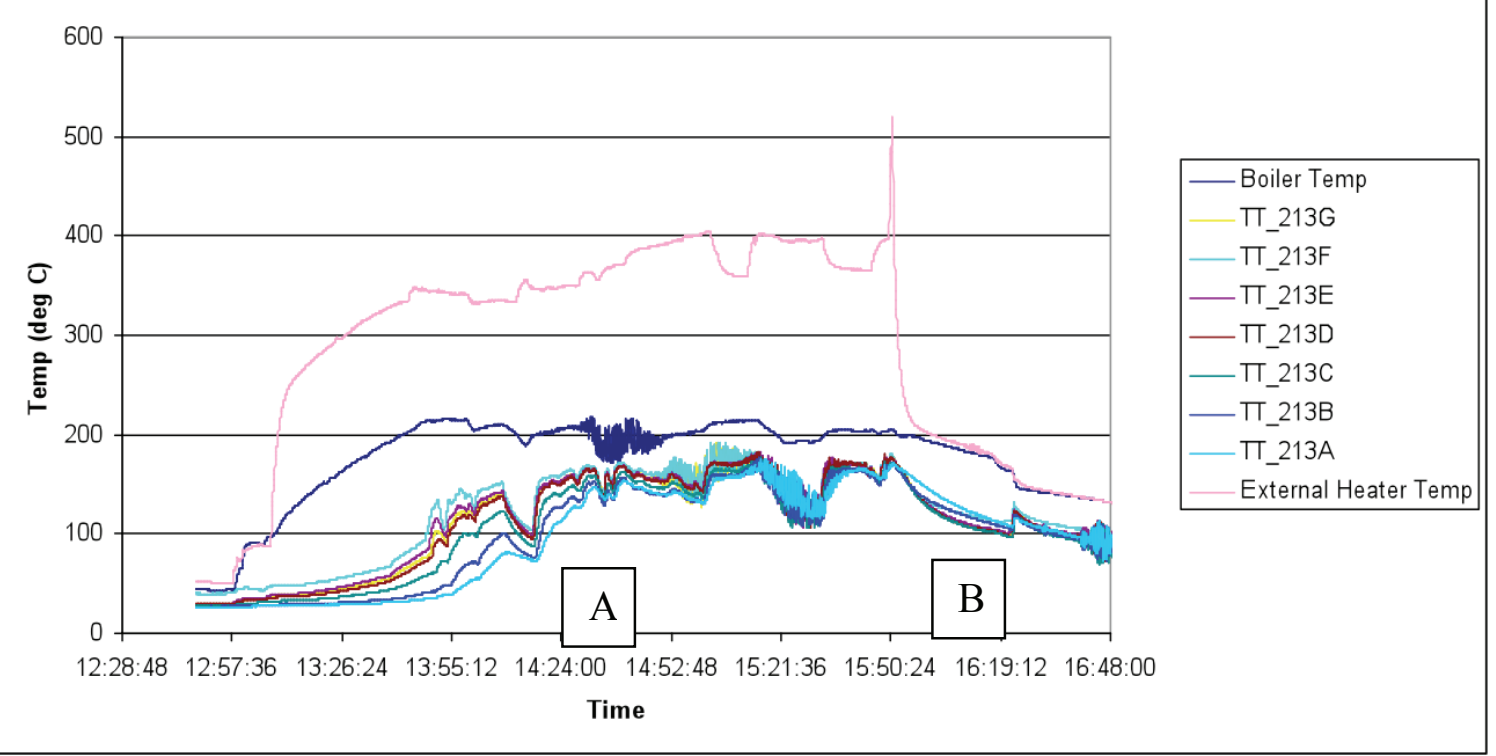

Figure 3.11. Typical HI distillation temperature profile.

\subsubsection{Summary of Results}

As the parameter space is explored, the primary variable being investigated is the operating pressure. Several runs have been conducted at pressures ranging from 45-200 psig. The primary affects of the pressure are: 1) the hydrogen production rate and 2) the HI distillation boiler temperature.

The system pressure affects $\mathrm{H}_{2}$ production rate by affecting the HI recycle. As the decomposition step is only $20 \%$ efficient, the un-reacted HI needs to be recycled in order to achieve the target production rates. This recycle is achieved by cooling the $\mathrm{HI} / \mathrm{H}_{2}$ stream to $\sim 5^{\circ} \mathrm{C}$ after the iodine has been removed. The vapor pressure of $\mathrm{HI}$ at this temperature is $66.15 \mathrm{psia}$. As the system pressures exceeds this value, the percentage of HI liquefied increases as the vapor fraction of HI decreases by Henry's Law:

$$
\mathrm{Y}_{\mathrm{HI}}=\mathrm{P}_{\mathrm{HI}} / \mathrm{P}_{\mathrm{tot}}
$$

As the total pressure increases, a larger fraction of $\mathrm{HI}$ is condensed to liquid, and recycled back to the reactor. The hydrogen production as function of pressure is shown in Fig. 3.12. 


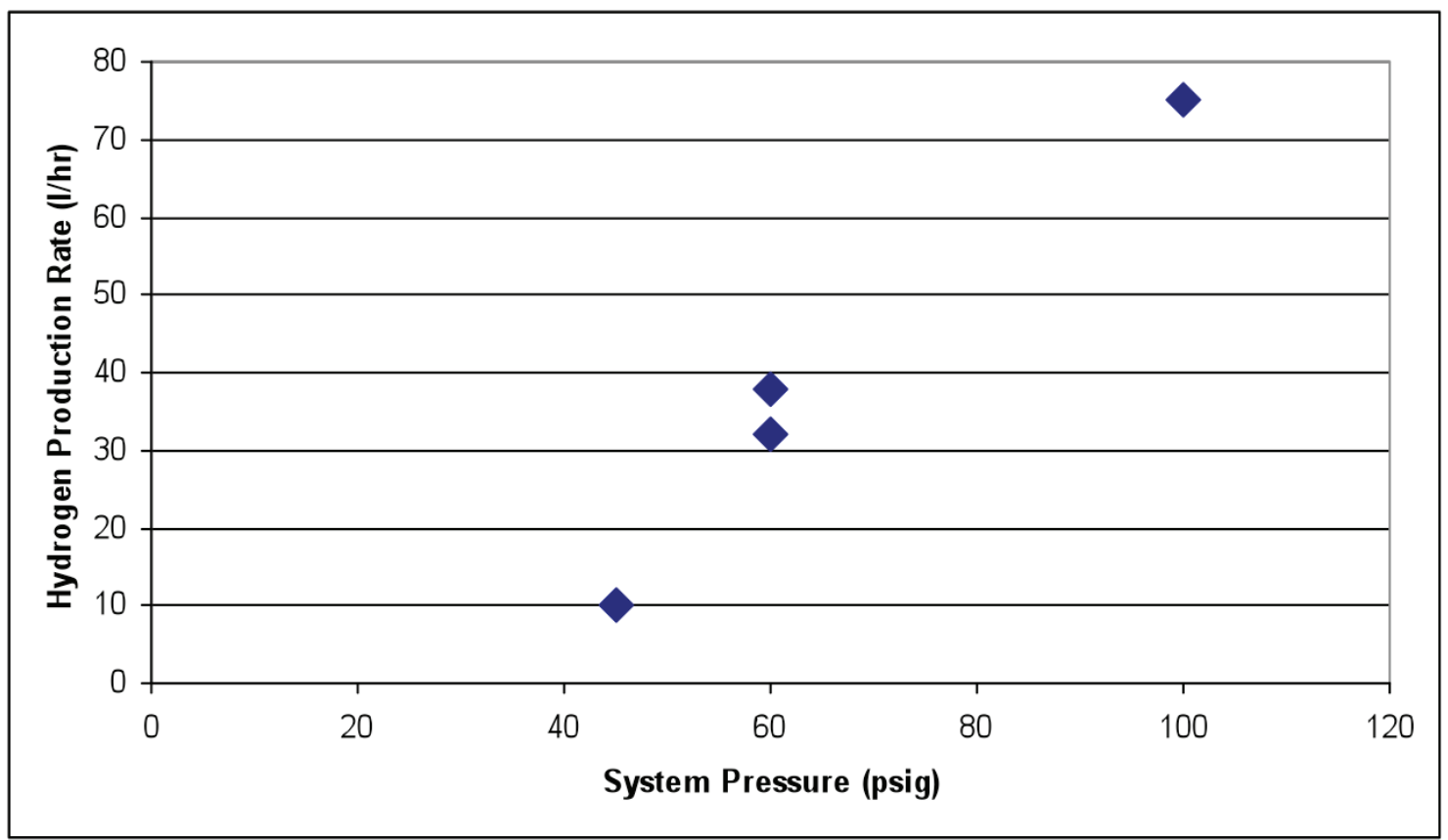

Figure 3.12. $\mathrm{H}_{2}$ production rate as a function of pressure.

The system pressure also affects the HI distillation boiler temperature. Figure 3.13 illustrates this affect. The boiler temperature becomes an issue as we study the long-term material compatibility in the system. In the following section, details of some materials issues with the $\mathrm{Ta} / 10 \% \mathrm{~W}$ tubing are identified.

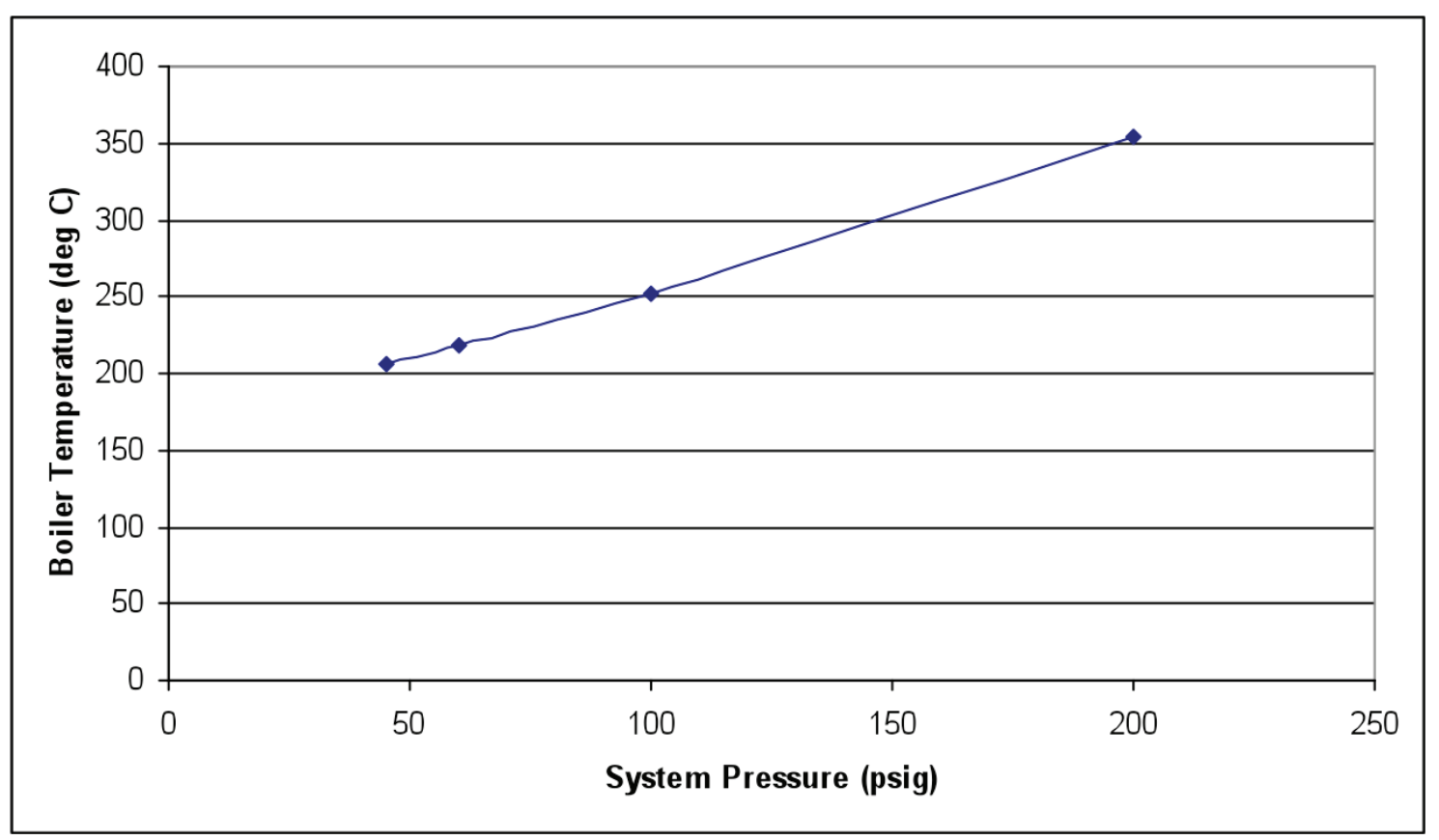

Figure 3.13. Pressure affect on HI distillation boiler temperature. 


\subsubsection{Technical Issues}

One of the goals of the ILS is being looking at materials issues. As the HI Decomposition skid has been operated on a more routine basis, we can now begin to evaluate the performance of the various materials in the system.

One area of concern that has been identified is with the tantalum $/ 10 \%$ tungsten alloy used for the process lines and vessels. There have been two instances where the 2-in. diameter $\mathrm{Ta} / 10 \% \mathrm{~W}$ tube, which is used for process vessels, has failed, as well as a section of the 0.5 -in. diameter tubing, which is used for the process lines. In all cases, the failure did not occur during operation, but during routine, off-line maintenance.

For the case of the $1 / 2$-in. tubing failure, the tubing failed at the connection to the Swagelok fitting. The material immediately downstream was very brittle, and continued to break as the material was trimmed.

The tubing in this area had been exposed to all process chemicals; $\mathrm{HI}, \mathrm{H}_{2} \mathrm{O}, \mathrm{H}_{3} \mathrm{PO}_{4}$ and $\mathrm{I}_{2}$. However, the maximum temperature exposure in this region was $180^{\circ} \mathrm{C}$, unlike a previous distillation column failure, which had been exposed to $+500^{\circ} \mathrm{C}$ conditions. As the tubing and the fitting immediately below it were examined, it was discovered the Ta coated fitting was severely corroded.

The lower temperature exposure, and the additional corrosion on the coated fitting lead to the conclusion that the failure mechanism in the $1 / 2$-in. tube is different from the previous failure in the distillation column. The distillation column had been exposed to higher temperatures, and showed clear evidence of Ta oxidation as well as the presence of phosphates at the surface. The $1 / 2$-in. tube did not show either of these conditions. The condition of the failed tube, excessive embrittlement and long cracks suggest $\mathrm{H}_{2}$ embrittlement. A mechanism has been proposed to explain this possibility, and further metrological tests are being conducted to validate this theory. If the Ta coating on the stainless steel fitting is damaged or scratched, the exposed stainless will be aggressively attacked. With the corrosion of the stainless, a localized electrochemical cell could be formed:

$$
\begin{aligned}
& \mathrm{Fe}+2 \mathrm{I}^{-} \rightarrow \mathrm{FeI}_{2}+2 \mathrm{e}^{-} \\
& 2 \mathrm{e}^{-}+2 \mathrm{H}^{+}+\mathrm{Ta} \rightarrow \mathrm{TaH}_{2}
\end{aligned}
$$

This process would explain the severely corroded Ta coated fitting as well as the $\mathrm{H}_{2}$ embrittled Ta, which can be more severe at lower temperature. This would also explain why the material failed as the system was shut down, and not under operating conditions, as the $\mathrm{H}_{2}$ is able to migrate into and back out of the Ta at elevated temperatures. Additional tests on the failed parts are currently underway to determine the validity of this mechanism. Table 5 summarizes the comparison of the distillation boiler failure and the $1 / 2$-in. tubing failure. 
Table 5. Status of Ta Material Failure

\begin{tabular}{|c|c|c|}
\hline Sample & Failure Mechanism & Status \\
\hline $\begin{array}{l}\text { Phosphoric acid } \\
\text { boiler }\end{array}$ & $\begin{array}{l}\text { Embrittlement due to } \\
\text { oxidation. Operating } \\
\text { temperature exceeded } \\
350^{\circ} \mathrm{C} \text {. }\end{array}$ & $\begin{array}{l}\text { Examination is on going at UNLV under } \\
\text { Prof. Allen Johnson. Phosphate was found } \\
\text { on sides of the boiler wall. Phosphate was } \\
\text { also found along on the transverse crack } \\
\text { surface indicating it may have diffused } \\
\text { through the boiler wall. He is in the } \\
\text { process of issuing a report. }\end{array}$ \\
\hline $\begin{array}{l}\text { Test tube section } \\
\text { sample inside } \\
\text { new phosphoric } \\
\text { acid boiler }\end{array}$ & No failure & $\begin{array}{l}\text { Phosphate and iron oxides was found on } \\
\text { top of the test sample by EDX at GA. } \\
\text { They can be removed easily thus they } \\
\text { were most likely from other part of the } \\
\text { system and were dried onto the sample. } \\
\text { Cross section of the section did not show } \\
\text { any phosphate penetration. }\end{array}$ \\
\hline $\begin{array}{l}\text { Overflow feed } \\
\text { tube and fitting }\end{array}$ & $\begin{array}{l}\text { Hydrogen } \\
\text { embrittlement. }\end{array}$ & $\begin{array}{l}\text { The stainless body of a Ta coated fitting } \\
\text { was found to have been corroded } \\
\text { extensively. Radial cracks were found in } \\
\text { the Ta-10W tubing. At the end of the Ta- } \\
\text { 10W tubing inside the fitting, corrosion on } \\
\text { the Ta tubing was also observed. Based on } \\
\text { these observations, it was concluded that } \\
\text { the Ta coating inside the fitting was } \\
\text { damaged thus leading to the acid attacking } \\
\text { the stainless body. As a result, an } \\
\text { electrochemical cell was formed with } \\
\text { stainless as the anode and Ta as the } \\
\text { cathode. Atomic hydrogen was formed on } \\
\text { the Ta surface and diffuses into the metal } \\
\text { causing embrittlement. More detail } \\
\text { metallography is on going at GA to } \\
\text { determine the exact failure mechanism. }\end{array}$ \\
\hline
\end{tabular}

Because of the materials issues, a more careful tracking of the boiler skin and heater temperature has been initiated. 


\subsubsection{Summary: GA Hydrogen Iodide Decomposition Section}

The HI Decomposition skid has achieved a semi-reliable, routine state of operations. The parameter space of operation is being investigated, with the achievement of $75 \mathrm{~L} / \mathrm{hr}$ $\mathrm{H}_{2}$ production accomplished. System operations are reliable and reproducible.

Even with the routine operations, there are several challenges and goals that need to be met. The materials issue needs to be more fully investigated and understood. A parallel effort has begun looking at Ta coated stainless steel as an alternative for the severe applications of the HI decomposition boiler and phosphoric acid concentrator. Additionally, more thorough testing in an integrated mode with the Bunsen skid is required to begin to explore the effects of off-spec feed compositions and other contaminants.

The next phase of operations for the HI Decomposition skid involves continuing to increase the system pressure to the design target of 200 psig, leading to a continued increase in $\mathrm{H}_{2}$ production rate. Additionally, the newly designed boilers will be constructed and tested. 


\section{SUMMARY}

The results from the initial integrated tests in April, 2008 provided some initial results for the integrated system, but these results also indicated major equipment modifications were required for the CEA hydrogen production process and the GA hydrogen iodide decomposition process. Although in the CEA process hydrogen iodide was produced, it was determined that additional modifications were required and a modified Bunsen reactor has been installed. Once the operational parameters for the Bunsen reactor have been identified integrated tests with all three process sections will be continued. In addition to replacement of the reactor, a new iodine pumping system, using pressure to transfer iodine from the chemical storage skid to the Bunsen reactor, has been installed and successfully operated. The hydrogen decomposition reactor in the General Atomics hydrogen decomposition process has been replaced with a smaller unit and the process has been successfully operated multiple times to produce hydrogen at a rate of $75 \mathrm{~L} / \mathrm{min}$. The Sandia National Laboratories acid decomposition process section has undergone several modifications to improve process efficiency and integrated operation. The most significant improvement is the installation of a backpressure regulator and buffer tank between the SNL section and the CEA section to prevent pressure fluxuations in the SNL acid decomposition reactor that can result in breakage of the unit. The SNL process has been successfully operated multiple times with sulfur dioxide produced at a rate of 100$200 \mathrm{~L} / \mathrm{hr}$. 
GENERAL ATOMICS

P.O. BOX 85608 SAN DIEGO, CA $92186-5608$ (858) 455-3000 